\title{
STATUS SUMBER DAYA IKAN TUNA SAMUDERA HINDIA: IMPLIKASINYA BAGI INDONESIA
}

\author{
Victor P. H. Nikijuluw
}

Peneliti pada Pusat Riset Perikanan Tangkap, Ancol-Jakarta

Teregristrasi I tanggal: 6 Pebruari 2007; Diterima setelah perbaikan tanggal: 26 Maret 2008;

Disetujui terbit tanggal: 25 April 2008

\begin{abstract}
ABSTRAK
Sumber daya ikan tuna di Samudera Hindia dikelola oleh 2 Regional Fisheries Management Organization yaitu Indian Ocean Tuna Commission dan Commission for the Conservation of the Blue Fin Tuna. Dengan pengolahan ini, maka sumber daya ini tidak lagi bebas dimasuki untuk dimanfaatkan, kecuali oleh negara atau entitas yang menjadi anggota ke-2 Regional Fisheries Management Organization ini. Sumber daya tuna ini telah dimanfaatkan sejak tahun 1950, dan mungkin akan terus menjadi daerah penangkapan utama di masa mendatang. Jenis-jenis tuna ukuran besar sudah cenderung ditangkap secara berlebihan. Sementara jenis tuna ukuran kecil cenderung belum tinggi intensitas penangkapan. Indonesia sudah saatnya mengembangkan perikanan tuna di Samudera Hindia ini secara besar-besaran, mengingat posisi geografis Indonesia yang relatif lebih dekat dan berbatasan langsung dengan Samudera Hindia.
\end{abstract}

\section{KATA KUNCl: Samudera Hindia, tuna, Regional Fisheries Management Organization}

ABSTRACT: The state of Indian Ocean tuna fisheries: An implication for Indonesia. By: Victor P. H. Nikijuluw

Indian Ocean tuna resources are managed by two Regional Fisheries Management Organization; the Indian Ocean Tuna Commission and Commission for the Conservation of the Blue Fin Tuna. Under this management regime, the fishery is not an open access. It can only be utilized by member countries and entities of the those Regional Fisheries Management Organization. The tuna resources have been extensively caught since 1950, and may be kept on being exploited in the future. The large tuna species tended to have been fully utilized, while the small species may be considered under fished. Indonesia should develop its capacity to the best use of the existing resources, considering its relatively shorter distance to the fishing ground.

\section{KEYWORDS: Indian Ocean, tuna, Regional Fisheries Management} Organization

\section{PENDAHULUAN}

Adalah suatu fakta geografis bahwa negara kepulauan Indonesia berbatasan langsung dengan Samudera Hindia. Oleh karena itu, adalah wajar bagi Indonesia memanfaatkan sumber daya ikan yang terkandung di perairan tersebut.
Pemanfaatan tersebut pada hakekat tidak dibatasi di dalam perairan Zona Ekonomi Eksklusif Indonesia, tetapi juga dapat melampaui batas-batas Zona Ekonomi Eksklusif Indonesia, meliputi seluruh kawasan Samudera Hindia. Akan tetapi pemanfaatan sumber daya ikan di luar perairan Zona Ekonomi Eksklusif Indonesia 
oleh nelayan Indonesia hanya dapat dilakukan dan diakui oleh masyarakat internasional bila Indonesia bergabung dalam organisasi pengolalaan perikanan regional atau Regional Fisheries Management Organization.

Samudera Hindia merupakan wilayah kompetensi (competent area) bagi setidaknya 2 Regional Fisheries Management Organization, yaitu Commission for the Conservation of the Blue Fin Tuna dan Indian Ocean Tuna Commission. Ke-2 organisasi ini adalah himpunan negara atau entitas yang mau bekerjasama dalam pengelolaan dan pemanfaatan sumber daya ikan di Samudera Hindia. Di luar ke-2 organisasi ini, hampir pasti akan sulit bagi negara atau entitas lain melakukan kegiatan eksploitasi sumber daya ikan di Samudera Hindia. Kalaupun ada negara atau entitas lain yang melakukan kegiatan tersebut, pada umumnya kegiatan itu digolongkan oleh Regional Fisheries Management Organization serta masyarakat internasional lainnya sebagai suatu kegiatan ilegal. Dengan begitu, nelayan negara pantai seperti Indonesia ataupun negara lainnya yang tidak berbatasan dengan Samudera Hindia mau tidak mau dipaksa untuk menjadi anggota Regional Fisheries Management Organization, bila mau memanfaatkan sumber daya ikan yang tersedia di perairan ini (Ward, et al., 2002).

Sebagai bagian dari Samudera Hindia, Zona Ekonomi Eksklusif Indonesia Indonesia yang pada dasarnya adalah termasuk yurisdiksi nasional diikutkan juga sebagai wilayah kompetensi Indian Ocean Tuna Commission. Demikian pula, dengan Zona Ekonomi Eksklusif Indonesia negara pantai lainnya yang terletak di Samudera Hindia. Hal ini merupakan isu sensitif dan kontraversial yang diselesaikan Regional Fisheries Management Organization.
Konflik terjadi antara kepentingan nasional dan regional. Bagi sebagian pakar hukum internasional dimasukkannya perairan teritorial negara pantai tertentu sebagai lahan kompetensi Regional Fisheries Management Organization dinilai menyalahi konvensi hukum laut internasional. Hal tersebut juga dinilai melanggar kedaulatan suatu negara.

Sementara kotraversial wilayah kompetensi Regional Fisheries Management Organization yang tumpang tindih dengan Zona Ekonomi Eksklusif Indonesia negara pantai belum diselesaikan, ternyata kehadiran Regional Fisheries Management Organization sebagai organisasi regional makin diakui dan dirasakan manfaatnya. Regional Fisheries Management Organization bukan menata pengelolaan sumber daya ikan di laut, tetapi secara perlahan-lahan sudah menentukan kuota dan syarat perdagangan internasional. Dengan berlakunya prinsipprinsip traceability (ketertelusuran) pada perdagangan internasional produk perikanan, maka kegiatan dan proses produksi menjadi hal penting dan tidak terpisahkan dengan kegiatan perdagangan. Di sini, peran Regional Fisheries Management Organization semakin nyata.

Peran Regional Fisheries Management Organization seperti ini terjadi, antara lain karena sumber daya ikan dunia yang semakin berkurang untuk diakses oleh baik negara pantai maupun negara lainnya. Kegiatan konservasi dan pengelolaan sumber daya ikan penting untuk dilaksanakan demi menjamin keberlanjutan sumber daya. Di sisi lain, Samudera Hindia dinilai sebagai kawasan yang menjanjikan untuk menjawab tantangan dan kondisi sumber daya ikan dunia yang telah mengalami deplesi. Karena itu, bukan negara pantai yang ikut serta dalam pemanfaatan dan pengelolaan sumber daya 
ikan Samudera Hindia, tetapi juga negara lain yang tidak berbatasan langsung dengan perairan ini.

Sebagai contoh, meskipun Jepang, Korea Selatan, dan Philipina tidak berbatasan langsung dengan Samudera Hindia, akan tetapi ke-3 negara ini terdaftar sebagai anggota di Commission for the Conservation of the Blue Fin Tuna dan Indian Ocean Tuna Commission. Bahkan negara yang lebih jauh letaknya seperti Paruguay dan Uni Eropa juga ikut sebagai anggota Indian Ocean Tuna Commission. Dengan ikut serta sebagai anggota, maka nelayan ke-3 negara ini dapat menangkap ikan di Samudera Hindia. Hal ini berarti bahwa nelayan di ke-3 negara tersebut memiliki peluang usaha yang lebih besar, bahkan dibandingkan dengan Timor Leste umpamanya yang berbatasan dengan Samudera Hindia, namun bukan sebagai negara ke-2 Regional Fisheries Management Organization itu.

Regional Fisheries Management Organization-Commission for the Conservation of the Blue Fin Tuna berkonsentrasi dalam pengelolaan, konservasi, dan pemanfaatan sumber daya ikan tuna sirip biru (southern blue fin tuna). Sementara Regional Fisheries Management Organization-Indian Ocean Tuna Commission, sesuai namanya, berkonsentrasi dalam pengelolaan dan pemanfaatan ikan-ikan jenis tuna. Namun, karena keterkaitan biologis antara tuna dan jenis ikan lainnya baik sebagai mangsa atau predator, atau juga karena ikan-ikan itu hidup pada habitat yang sama serta dipengaruhi oleh kegiatan penangkapan ikan dengan teknologi yang sama, maka pada akhir-akhir ini ke-2 Regional Fisheries Management Organization tersebut ini tidak melaksanakan kegiatan yang berkenan hanya dengan tuna tetapi juga dengan ikanikan jenis lain yang memiliki keterkaitan dan hubungan.

Makalah ini membahas status sumber daya ikan tuna di Samudera Hindia. Bahan utama makalah ini berasal dari Indian Ocean Tuna Commission Report of the Ninth Session of the Scientific Committee Meeting yang diadakan di Victoria Seychelles, 6-10 Nopember 2006 (Indian Ocean Tuna Commission, 2008). Kecuali southern blue fin tuna, ikan tuna jenis lain yang dibahas pada makalah ini adalah:

1. Tuna albakora (Thunnus alalunga), atau albacore.

2. Tuna mata besar (Thunnus obesus) atau big eye tuna.

3. Cakalang (Katsuwonus pelamis) atau skip jack tuna.

4. Madidihang (Thunnus albacares) atau yellow fin tuna.

5. Ikan pedang (Xiphius gladius) atau sword fish.

6. Tongkol lisong (Auxis rochei) atau bullet tuna.

7. Deho (Auxis thazard), atau frigate tuna.

8. Tenggiri papan (Scomberomorus guttatus) atau king makerel.

9. Tongkol abu-abu (Thunnus tonggol) atau longtail tuna.

10. Tenggiri (Scomberomorus commerson) atau spanish mackerel

\section{TUNA ALBAKORA (Thunnus alalunga)}

Tuna albakora (Thunnus alalunga) hidup pada kawasan $5^{\circ} \mathrm{LU}$ sampai dengan $40^{\circ}$ LS. Diduga hanya ada 1 populasi albokara di Samudera Hindia, tidak seperti di Samudera Pasifik dan Atlantik yang diduga memiliki lebih dari 1 populasi. Meskipun begitu, ada indikasi bahwa albakora dapat saling melintasi Samudera Hindia dan Atlantik. 
Ikan ini termasuk perenang cepat. Ikan remaja (berusia 2 sampai 5 tahun) lebih tinggi tingkat migrasinya dibanding dengan yang lebih tua usia. Migrasi, distribusi, serta besar-kecil populasi secara alamiah sangat tergantung pada kondisi oseanografis, utamanya gelombang laut, arus, dan ketersediaan makanan alami. Beberapa penelitian membuktikan bahwa sistem pernapasan yang dimiliki membuat ikan tuna terus berenang. Manakala berhenti berenang, albakora dan sejenisnya akan mengalami masalah pernapasan dan mati.

Daerah pemijahan albakora adalah perairan Madagaskar pada posisi $15^{\circ}$ sampai $25^{\circ} \mathrm{LS}$. Periode pemijahan adalah pada kuartal pertama dan ke-4 setiap tahun. Ikan ini memiliki pertumbuhan yang lambat, mencapai dewasa pada usia 5 sampai 6 tahun. Seperti pada ikan tuna lainnya, albakora memijah pada perairan dengan suhu di atas $25^{\circ} \mathrm{C}$. Dengan kata lain, pemijahan dilakukan di perairan tropis. Habitat dan daerah penangkapan ikan ini adalah bagian barat Samudera Hindia. Bila tertangkap di perairan barat Pulau Sumatera, itu terjadi karena albakora bermigrasi untuk mencari makan, mengikuti arus dan gelombang laut.

Sejak tahun 1956, albakora sudah mulai ditangkap oleh nelayan purse seine Taiwan dan dan long line Jepang. Korea Selatan mulai menangkap ikan ini secara komersial pada 1965 dengan menggunakan long line. Armada long line Indonesia mulai secara komersial menangkap ikan ini pada 1974.

Pada tahun 1986, armada gill net Taiwan dan Tiongkok secara besarbesaran dikembangkan untuk menangkap albakora. Namun, karena produktivitas yang sangat tinggi dan dinilai mengancam keberlanjutan sumber daya, maka operasi armada penangkapan dengan menggunakan gill net dihentikan sejak tahun 1992. Saat ini, stok sumber daya albakora Samudera Hindia dieksploitasi oleh armada purse seine Perancis dan Spanyol, armada long line Taiwan, Indonesia, Jepang, Seychelles, France-Reunion, dan Korea Selatan, serta armada gill net Tiongkok. Albakora adalah sasaran penangkapan maupun hasil sampingan dari industri penangkapan tuna lain.

Produksi albakora cenderung stabil sejak sumber daya ini dimanfaatkan secara komersial yaitu pada periode tahun 1950an sampai 1980-an. Hasil tangkapan kemudian meningkat tajam di era tahun 1990-an sampai awal 2000-an, karena penggunaan gill net yang memang sangat produktif. Produksi total albakora mencapai lebih dari 30.000 ton pada tahun 1990 serta 1996 sampai 2002. Tetapi produksinya menurun sampai berada pada posisi 19.000 ton pada 2005. Dari produksi tahun 2005 , sekitar 2,700 ton disumbangkan oleh long line Indonesia.

Upaya untuk menghitung potensi lestari albakora Samudera Hindia dilakukan pada tahun 2004. Namun, hasil estimasi potensi lestari belum dapat dikatakan, kecuali indikasi bahwa hasil tangkapan rata-rata dalam 5 tahun terakhir (sekitar 28.200 ton per tahun) sudah tidak lestari, atau pada tingkat yang mulai mengancam keberlanjutan sumber dayanya. Selain itu, juga semakin kecil ukuran albakora yang tertangkap menandakan bahwa sumber daya ini sudah mulai mengalami deplesi akibat tekanan penangkapan.

\section{TUNA MATA BESAR (Thunnus obesus)}

Tuna mata besar (Thunnus obesus) hidup di perairan tropis dan sub tropis Samudera Hindia, Pasifik, dan Atlantik pada kedalaman air mencapai $300 \mathrm{~m}$. Juvenil pada umumnya hidup di bawah benda yang mengapung, seperti rumpon, bersama 
dengan juvenil jenis madidihang (Thunnus albacares) dan cakalang (Katsuwonus pelamis). Namun, semakin besar dan dewasa, semakin jarang tuna mata besar ditemukan pada benda yang mengapung (floating object).

Penelitian mengindikasikan bahwa hanya ada 1 populasi tuna mata besar di Samudera Hindia. Ikan-ikan yang dalam kondisi matang gonad pada umumnya tertangkap di perairan tropis. Oleh karena itu dapat disimpulkan bahwa daerah pemijahan tuna mata besar adalah pada kawasan tropis. Sementara itu, perairan sub tropis adalah habitat di mana ikan ini hidup, tumbuh dan mencari makan.

Di antara jenis-jenis tuna, tuna mata besar yang paling panjang usia. Ditaksir lebih dari 15 tahun. Oleh karena itu pula, ikan ini lebih rentan terhadap perubahanperubahan ekosistem serta penangkapan oleh manusia. Tuna mata besar dapat mencapai lebih dari 2,0 m panjang total, dan bobot mencapai $200 \mathrm{~kg}$. Ikan ini mulai bereproduksi pada usia sekitar 3 tahun pada saat panjang tubuh mencapai 1,0 m. Dengan demikian, bila tertangkap pada ukuran kurang dari 1,0 m, itu berarti ikan tersebut belum sempat bereproduksi.

Tuna mata besar mulai ditangkap secara komersial oleh armada long line Taiwan dan Jepang pada awal tahun 1950-an. Di awal tahun 1960-an, Korea Selatan mulai menangkap ikan ini. Armada long line Indonesia mulai ikut menangkap tuna mata besar pada awal tahun 1970-an. Pada awal tahun 1980-an, armada purse seine Perancis, Spanyol, dan Seychelles mulai juga menangkap tuna mata besar.

Di barat Samudera Hindia, tuna mata besar pada umumnya ditangkap dengan menggunakan purse seine. Oleh karena itu pula, ikan berukuran kecil dan juvenil, rata- rata $5 \mathrm{~kg}$ bobot, sering ikut tertangkap. Purse seine memang adalah alat penangkapan ikan yang rendah selektivitasnya. Di timur Samudera Hindia, armada long line menangkap ikan ukuran besar, rata-rata $40 \mathrm{~kg}$ bobot, untuk dipasarkan dalam bentuk dan kondisi segar. Karena penangkapan ikan ini relatif sulit, pada perairan yang relatif lebih dalam, maka armada perikanan rakyat jarang menangkap ikan ini. Dengan kata lain, perikanan tuna mata besar adalah perikanan industri, bukan perikanan rakyat atau artisanal. Di Indonesia, armada perikanan long line milik rakyat mampu menangkap ikan ini.

Produksi tuna mata besar berkembang sejalan bertambahnya armada penangkapan. Pada tahun 1956, produksinya 12.800 ton, secara perlahan dan pasti meningkat menjadi 24.100 ton pada tahun 1966, kemudian 28.700 ton pada tahun 1976, terus menanjak mencapai 126.900 ton pada tahun 1996 . Setelah itu, produksinya bertahan di atas 100.000 ton, dengan puncak produksi 150.000 ton pada tahun 1999. Selama 5 tahun terakhir, produksi rata-rata per tahun sekitar 122.800 ton. Pada tahun 2005, produksinya berada pada 112.400 ton. Produksi tuna mata besar Indonesia mencapai 9.300 ton pada tahun 2005.

Estimasi potensi sumber daya tuna mata besar yang dilakukan pada tahun 2006 muncul dengan angka 111.200 ton per tahun. Dibandingkan dengan produksi pada tahun 2005 serta rata-rata produksi tahunan selama 5 tahun terakhir, dapat dikatakan bahwa tingkat pemanfaatan sumber daya tuna mata besar sudah di sekitar puncak potensinya. Namun demikian, belum banyak informasi yang tersedia tentang ukuran dan usia ikan yang tertangkap serta hasil tangkapan per unit upaya. Akan tetapi, ketiadaan informasi ini bukan berarti bahwa 
produksi dapat ditingkatkan dengan menambah kapasitas penangkapan, tetapi sebaliknya kapasitas penangkapan tetap dipertahankan menurut prinsip atau pendekatan kehati-hatian (precautionary approach).

\section{CAKALANG (Katsuwonus pelamis)}

Cakalang (Katsuwonus pelamis) adalah tuna yang digolongkan sebagai spesies kosmopolitan yang hidup pada perairan tropis di 3 samudera yaitu Hindia, Atlantik, dan Pasifik. Cakalang cenderung bergerombol dalam ukuran besar, sering bersama dalam suatu gerombolan dengan juvenile tuna mata besar (Thunnus obesus) dan madidihang (yellow fin tuna). Di Indonesia, cakalang merupakan jenis ikan yang diperoleh hampir di semua wilayah perairan, khususnya di kawasan timur Indonesia.

Cakalang memiliki kemampuan reproduksi yang lebih tinggi dibandingkan tuna lainnya. Umurnya dapat mencapai 5 tahun, dan pada umumnya ditangkap pada usia 3 tahun. Pada kondisi perairan yang cocok untuk pemijahan, cakalang dapat memijah sepanjang tahun dalam jumlah cukup besar. Cakalang memijah di sekitar perairan khatulistiwa dengan suhu air sekitar $24{ }^{\circ} \mathrm{C}$. Ukuran mulai matang gonadnya sekitar 41 sampai $43 \mathrm{~cm}$. Karena rata-rata ukuran ikan yang tertangkap di Samudera Hindia lebih dari $43 \mathrm{~cm}$ panjang, maka dapat dikatakan bahwa ikan-ikan itu telah mengalami proses pemijahan atau reproduksi.

Rata-rata bobot cakalang yang tertangkap yaitu 3,0 sampai 3,5 per $\mathrm{kg}$. Armada gill net menangkap cakalang yang rata-rata lebih besar ukurannya dari alat tangkap lainnya. Cakalang yang tertangkap purse seine berukuran rata-rata 2,8 kg per ekor, huhate $3,0 \mathrm{~kg}$ per ekor, dan gill net
4,0 kg. Ini memberikan indikasi bahwa penggunaan gill net lebih ramah lingkungan dan menjamin keberlanjutan sumber daya. Oleh karena itu, pengaturan mata jaring gill net patut dilakukan agar supaya keberlanjutan sumber daya ini dapat terjamin.

Sejauh ini diasumsikan bahwa hanya ada 1 stok cakalang di Samudera Hindia. Namun, karena cakalang relatif dekat jarak bermigrasinya dari pada jenis tuna lainnya, maka sumber daya ikan ini dikelola atau ditata secara lokal. Cakalang lebih tahan terhadap perubahan-perubahan lingkungan dibandingkan dengan jenis tuna lainnya.

Di Samudera Hindia, cakalang ditangkap oleh armada penangkapan yang berasal dari banyak negara. Perikanan purse seine digunakan oleh Perancis, Spanyol, Seychelles, Rusia, Iran, dan Jepang. Perikanan huhate digunakan oleh Maladewa. Gill net digunakan oleh Indonesia, Sri Lanka, Pakistan, dan Iran. Long line digunakan oleh Indonesia. Penangkapan cakalang perlahan-lahan bergeser dari penangkapan kelompok yang berenang bebas (free schooling) ke yang berkumpul di sekitar rumpon. Namun, penangkapan dengan purse seine di sekitar rumpon memiliki dampak lingkungan sumber daya yang pada akhirnya sangat merugikan. Hal ini terkait dengan sifat perikanan purse seine yang memang rendah sifat selektivitasnya sehingga menangkap cakalang berukuran kecil.

Produksi cakalang menanjak dengan perlahan dari sekitar 20.000 ton pada tahun 1950-an menjadi 50.000 ton pada tahun $1970-a n$. Peningkatan produksi ini karena penggunaan huhate dan gill net. Produksi meningkat secara tajam pada tahun 1980an dengan dioperasikannya armada purse seine. Produksi mencapai 400.000 ton pada pertengahan tahun 1990-an dan 
berfluktuasi di antara 500.000 sampai 580.000 ton sejak tahun 1999. Produksi tahun 2005 mencapai 581.700 ton dan merupakan produksi tahunan tertinggi selama ini.

Sekitar $80 \%$ hasil tangkapan purse seine berkaitan dengan penggunaan rumpon. Demikian pula, hampir semua armada huhate di Maladewa menangkap ikan di sekitar rumpon. Stok yang berenang bebas tidak lagi menjadi tujuan utama operasi penangkapan karena biaya bahan bakar yang meningkat yang membuat operasi penangkapan cakalang tidak efisien secara ekonomi.

Produksi purse seine meningkat di 3 daerah penangkapan utama, yaitu di timur Somalia, Mozambique, dan utara Seychelles. Daerah produksi lainnya yaitu perairan barat dan selatan Indonesia. Dalam jumlah yang relatif kecil, cakalang juga masuk ke perairan Laut Arab dan ditangkap oleh armada perikanan Iran.

Armada purse seine Spanyol mendaratkan cakalang terbanyak, diikuti oleh armada gill net Indonesia dan Sri Lanka. Jepang, Korea Selatan, Taiwan, dan Cina tidak begitu memberi perhatian bagi penangkapan cakalang. Hal ini disebabkan karena harga cakalang yang relatif murah dibandingkan tuna lainnya, di samping konsumsi domestik yang relatif rendah di negara-negara ini. Produksi Indonesia pada tahun 2005 mencapai 108.800 ton atau sekitar 20\% dari produksi cakalang Samudera Hindia.

Sejauh ini belum diketahui informasi kuantitaif potensi sumber daya cakalang. Perkembangan dan trend produksi belum menunjukkan adanya masalah deplesi stok sumber daya cakalang. Trend produksi berbanding lurus dengan trend penggunaan armada. Semakin besar jumlah armada, semakin besar produksinya. Akan tetapi, hal ini tidak berarti bahwa cakalang dapat ditangkap secara bebas. Ukuran cakalang yang menjadi sasaran penangkapan patut menjadi perhatian. Diharapkan ikan yang tertangkap melebihi ukuran $40 \mathrm{~cm}$ yang berarti bahwa ikan tersebut telah sempat bereproduksi sebelum tertangkap.

\section{MADIDIHANG (Thunnus albacares)}

Madidihang (Thunnus albacares) atau tatihu, juga merupakan jenis tuna kosmopolitan yang hidup di kawasan tropis dan sub tropis Samudera Hindia, Pasifik, dan Atlantik. Jenis tuna ini sering berasosiasi dalam gerombolan yang sama dengan cakalang (Katsuwonus pelamis) dan juvenil tuna mata besar (Thunnus obesus). Karena itu pula, maka ke- 3 jenis tuna ini sering tertangkap oleh alat armada yang sama. Juvenil madidihang (baby tuna) ditemukan di permukaan perairan tropis. Ikan dewasa ditangkap di perairan yang lebih dalam. Sekitar 20 sampai $25 \%$ perikanan madidihang dihasilkan oleh armada perikanan rakyat, utamanya di perairan LautArab.

Analisis DNA sejauh ini tidak mengindikasikan bahwa sumber daya madidihang di Samudera Hindia terdiri atas beberapa populasi atau sub populasi. Jadi dapat dikatakan bahwa hanya ada 1 populasi madidihang di Samudera Hindia. Meskipun daerah penangkapan terkonsentrasi di 2 lokasi yaitu pantai barat Sumatera dan pantai timur Afrika.

Periode pemijahan dari bulan Desember sampai Maret di perairan sekitar khatulistiwa sampai $10^{\circ}$ LS. Daerah pemijahan utama yaitu pada $75^{\circ} \mathrm{BT}$, pantai Sri Lanka, perairan Mozambique, dan pantai barat Australia. Sejauh ini sudah terbukti bahwa Laut Arab adalah tempat di mana madidihang mencari makan dan 
tumbuh. Rekruitmen terjadi pada bulan Juli. Matang gonad pertama kali terjadi pada ukuran ikan sekitar $100 \mathrm{~cm}$. Ukuran madidihang $150 \mathrm{~cm}$ yang tertangkap didominasi oleh jantan.

Sumber daya madidihang Samudera Hindia sudah mulai dimanfaatkan secara komersial sejak berakhir Perang Dunia II. Pada saat ini, armada long line Jepang mendaratkan sekitar $90 \%$ produksi total Samudera Hindia. Negara-negara lain, dalam jumlah yang terbatas, turut memanfaatkan sumber daya ini, yaitu Maladewa, Sril Lanka, Oman, Pakistan, dan Indonesia. Namun, Jepang sangat mendominasi perikanan ini.

Di awal tahun 1980-an, armada purse seine Eropa, terutama dari Spanyol dan Perancis, mulai menangkap sumber daya ini. Demikian pula, negara-negara di Afrika Timur, Afrika Selatan, dan Laut Arab ikut serta memanfaatkan sumber daya ini. Hal ini membuat produksi madidihang melonjak dari di bawah 100.000 ton per tahun pada tahun 1970-an menjadi di atas 200.000 ton pada tahun 1980-an.

Produksi terus meningkat dengan semakin banyak negara, termasuk Uni Eropa, ikut menangkap ikan ini. Pada tahun 1993, produksi bahkan menembusi 400.000 ton, $25 \%$ diantaranya disumbangkan oleh armada long line Taiwan. Periode tahun 1994 sampai 2002, produksi tahunan di bawah 300.000 ton, kemudian naik lagi mencapai 500.000 ton pada 2004, disebabkan oleh beroperasinya purse seine Spanyol, Perancis, dan Seychelles. Pada tahun 2005, produki turun lagi menjadi 408.000 ton. Dari armada long line Indonesia menyumbangkan 13.000 ton dan armada gill net Indonesia menyumbangkan 3.200 ton.
Diperkirakan, potensi lestari sumber daya madidihang Samudera Hindia sekitar 300.000 sampai 350.000 ton per tahun. Dibandingkan dengan produksi tahun 2005 sekitar 484.700 ton dan tahun 2004 sekitar 506.900 ton, maka dapat disimpulkan bahwa sumber daya madidihang di Samudera Hindia sudah dieksploitasi secara berlebihan. Posisi produksi di atas potensi lestari ini diperburuk oleh 3 hal berikut ini:

1. Penangkapan madidihang dengan menggunakan purse seine di sekitar rumpon yang mengakibatkan ikut tertangkapnya juvenil madidihang (baby tuna).

2. Penangkapan baby tuna oleh purse seine atau gill net yang ditujukan untuk menangkap cakalang (Katsuwonus pelamis).

3. Perkembangan teknologi purse seine yang sangat maju. Dengan penggunaan sonar, gerombolan madidihang pada jarak 5 km dapat dengan mudah dideteksi, baik siang maupun malam. Penggunaan sonar juga berkembang di kalangan perikanan skala kecil atau artisanal.

\section{IKAN PEDANG (Xiphius gladius)}

Ikan pedang (Xiphius gladius) menjadi penting sebagai ikan konsumsi mulai tahun 1990-an ketika dunia mulai mengalami kelangkaan ikan, akibat bertambahnya penduduk dan makin tingginya kesadaran manusia akan kedudukan ikan sebagai menu sehat. Diduga, perburuan ikan pedang akan meningkat di dekade yang akan datang sejalan dengan semakin bertambahnya permintaan ikan oleh pasar dunia.

Ikan pedang merupakan salah satu predator tingkat tinggi yang mendiami 
seluruh samudera di dunia. Di Samudera Hindia, ikan pedang diperkirakan hidup di perairan pesisir di sekitar khatulistiwa sampai $50^{\circ} \mathrm{LS}$. Ikan ini melakukan migrasi vertikal harian, dari permukaan air pada malam hari ke kedalaman $1.000 \mathrm{~m}$ pada siang hari. Migrasi vertikal ini pun ada kaitannya dengan distribusi Chepalapoda sebagai mangsa. Berbeda dengan jenisjenis tuna, ikan pedang tidak bersifat bergerombol, meskipun sering ditemukan dalam kelompok atau kawanan.

Penelitian genetik terhadap ikan ini gagal untuk membuktikan bahwa ikan-ikan ini memiliki populasi yang berbeda di Samudera Hindia. Oleh karena itu, untuk kepentingan pendugaan stok serta pengelolaan sumber daya, ikan pedang di Samudera Hindia diasumsikan hanya 1 populasi. Namun demikian, berdasarkan pada data produksi negara-negara pantai, dapat disimpulkan bahwa telah terjadi deplesi stok secara lokal di beberapa perairan pantai.

Ikan pedang hidup lebih dari 30 tahun. Bertumbuh dengan sangat cepat, mencapai sekitar $1 \mathrm{~m}$ panjang (sekitar $15 \mathrm{~kg}$ ) pada usia 1 tahun. Ikan pedang jantan mulai dewasa pada usia 1 sampai 3 tahun dengan panjang sekitar $170 \mathrm{~cm}$. Sementara itu, betina mulai dewasa pada usia 5 sampai 7 tahun dengan panjang sekitar $120 \mathrm{~cm}$. Rata-rata ukuran ikan pedang tertangkap di Samudera Hindia yaitu 40 sampai $80 \mathrm{~kg}$.

Penangkapan ikan pedang di Samudera Hindia diawali oleh armada long line Jepang pada tahun 1950-an. Pada saat itu, memang ikan pedang belum menjadi sasaran penangkapan sehingga produksinya hanya sekitar 2.000 ton pada awal tahun 1950-an, meningkat dengan sangat lambat menjadi sekitar 5,000 ton pada awal tahun 1990-an. Namun, produksi kemudian meningkat secara signifikan sejalan dengan bertambahnya upaya penangkapan tuna. Pada tahun 1998, produksi ikan pedang Samudera Hindia mencapai 35.000 ton, didaratkan oleh lebih dari 20 negara. Pada tahun 2005, produksi ikan pedang Samudera Hindia hanya sekitar 26.200 ton, turun dari 31,700 ton pada tahun 2004.

Penurunan produksi ini mengindikasikan bahwa sumber daya ikan pedang Samudera Hindia sudah mulai ditangkap secara berlebihan. Rata-rata produksi tahunan selama kurun waktu tahun 2001 sampai 2005 yang berjumlah 30,200 ton di atas dugaan potensi lestari 23.540 sampai 27.000 ton. Dengan demikian, pengembangan perikanan ikan pedang patut dilakukan dengan hati-hati demi menjaga keberlanjutan sumber dayanya.

Sejak awal tahun 1990-an, Taiwan merupakan negara utama penghasil ikan pedang dari Samudera Hindia dengan pangsa produksi sekitar 40 sampai $60 \%$. Prestasi Taiwan ini karena menggunakan long line permukaan pada malam hari. Ini berbeda dengan long line Jepang yang pada umumnya menggunakan long line laut dalam untuk menangkap tuna pada siang hari. Negara lain yang mengembangkan armada khusus bagi penangkapan ikan pedang adalah Australia, Reunion France, Seychelles, dan Afrika Selatan. Alat tangkap yang digunakan oleh negaranegara ini adalah long line dengan bantuan cahaya pada malam hari. Armada long line Indonesia juga menangkap ikan pedang, meskipun bukan sasaran utama. Pada tahun 2005, produksi ikan pedang oleh long line Indonesia hanya mencapai 1.800 ton, sekitar $8 \%$ produksi Samudera Hindia.

\section{TONGKOL LISONG (Auxis rochei)}

Tongkol lisong (Auxis rochei) adalah spesies oseanik yang hidup di sekitar 
khatulistiwa perairan dunia, termasuk Samudera Hindia. Ikan ini juga termasuk spesies yang bermigrasi jauh dalam gerombolan besar. Ikan dewasa pada umumnya ditangkap di perairan dekat pantai yang memiliki salinitas yang tinggi. Di Indonesia, ikan ini banyak tertangkap di Pelabuhan Ratu, Sukabumi serta beberapa daerah pendaratan lain di pantai selatan Pulau Jawa.

Spesies ini adalah jenis tuna ukuran kecil, dapat mencapai $50 \mathrm{~cm}$ panjang, dan mulai bereproduksi pada ukuran sekitar 35 $\mathrm{cm}$. Ukuran ikan yang tertangkap pada umumnya sekitar 30 sampai $40 \mathrm{~cm}$. Karena kecil ukurannya, spesies ini juga menjadi mangsa ikan tuna ukuran besar. Tongkol lisong sendiri memangsa jenis-jenis ikan teri dan larva kepiting.

Nilai ekonomis tongkol lisong lebih rendah dibandingkan tuna lainnya. Oleh karena itu, ikan ini tidak menjadi tujuan penangkapan oleh armada internasional. Pada umumnya, tuna lisong ditangkap oleh perikanan rakyat. Produksi tuna lisong Samudera Hindia mencapai 2.000 ton pada tahun 1996 dan turun menjadi 1.400 ton pada tahun 2005. Sejauh ini, tidak tersedia data yang cukup untuk menduga potensi lestari tongkol lisong. Negara produsen utama adalah Indonesia, Sri Lanka, dan India.

\section{DEHO (Auxis thazard)}

Deho (Auxis thazard) juga termasuk tuna ukuran kecil. Dibandingkan dengan tongkol lisong (Auxis rochei), spesies ini lebih tinggi produksinya. Pada tahun 2005, produksinya mencapai 32.900 ton, hampir tidak berubah dibanding tahun sebelumnya. Namun, potensi lestari spesies ini di Samudera Hindia belum diketahui secara pasti.
Deho juga merupakan yang bermigrasi jauh, ditemukan pada umumnya di perairan pesisir yang bersalinitas tinggi. Spesies ini senang hidup berkelompok, 1 kelompok dengan ikan tenggiri (Scomberomerous sp.). Ukuran terpanjang ikan ini, pernah dikatakan mencapai $58 \mathrm{~cm}$. Di perairan lain, dikatakan bahwa ukurannya pernah mencapai $65 \mathrm{~cm}$. Ukuran pertama mulai bereproduksi, yaitu 29 sampai $35 \mathrm{~cm}$. Musim memijah pada bulan Agustus sampai April di selatan Khatulistiwa, serta bulan Januari sampai April di utara Khatulistiwa. Karena kecil ukurannya, deho juga sering menjadi mangsa tuna ukuran besar. Deho memangsa ikan-ikan yang berukuran lebih kecil, cumi-cumi dan plankton krustasea.

Negara produsen deho di kawasan Samudera Hindia adalah India, Sri Lanka, Indonesia, dan Maladewa. Armada gill net skala kecil digunakan oleh ke-4 negara ini.

\section{TONGKOL ABU-ABU (Thunnus tonggol)}

Tongkol abu-abu (Thunnus tonggol) adalah anggota keluarga tuna yang juga termasuk spesies oseanik. Spesies ini hidup di perairan paparan benua atau dengan kata lain pada perairan yang relatif dangkal dibanding dengan jenis tuna lainnya. Ikan ini dapat mencapai $145 \mathrm{~cm}$ panjang dan $35,9 \mathrm{~kg}$ bobot. Namun, ukurannya yang ditemukan di Samudera Hindia 40 sampai $70 \mathrm{~cm}$. Daerah pemijahannya di perairan pesisir, pada umumnya pada bulan Januari sampai April dan bulan Agustus sampai September. Makanan alami tongkol abu-abu adalah chepalopoda, krustasea, dan ikan-ikan ukuran kecil.

Produksi tongkol abu-abu di Samudera Hindia meningkat sejak tahun 1950 dengan puncak pada tahun 1980, 1988, 1995, dan 
2000. Pada tahun 1956, produksi hanya 3.200 ton, meningkat menjadi 53.400 ton pada tahun 2005. Selama tahun 2001 sampai 2005 , produksi rata-rata tahunan mencapai 60.600 ton.

Produsen utama tongkol abu-abu adalah Iran, diikuti oleh Oman, Pakistan, Yaman, India, dan Uni Emirate Arab. Di Asia Tenggara, Thailand dan Malaysia adalah negara produsen utama. Produksi Indonesia sangat kecil (kurang dari 1000 ton) sehingga tidak diperhitungkan sebagai negara penghasil tongkol abu-abu. Purse seine dan gill net adalah alat tangkap yang digunakan untuk menangkap spesies ini.

\section{TENGGIRI PAPAN (Scomberomorus guttatus)}

Tenggiri papan (Scomberomorus guttatus) merupakan salah satu ikan ekonomis penting di Indonesia yang ditangkap hampir di seluruh perairan Nusantara. Sumber daya ikan ini juga diikutkan sebagai salah satu spesies yang menjadi perhatian Indian Ocean Tuna Commission. Sejak tahun 1960, penangkapan tenggiri papan secara komersial telah dilakukan di Samudura Hindia. Produksinya cenderung meningkat sejalan dengan bertambahnya upaya penangkapan. Namun, pada tahun 2001 sampai 2005 , produksinya cenderung stabil sekitar 33.000 ton per tahun.

Tenggiri papan adalah spesies yang bermigrasi jauh, dalam kelompok kecil, memilih tinggal di perairan pesisir, dan sering kali masuk sampai ke perairan estuari. Ukuran panjang mencapai $76 \mathrm{~cm}$, mulai dewasa pada ukuran 48 sampai 52 $\mathrm{cm}$ atau pada usia 1 sampai 2 tahun. Semakin dewasa, semakin besar kemampuan reproduksinya. Ikan ini memiliki kemampuan reproduksi yang tinggi dan cepat pertumbuhannya. Oleh karena itu, sumber daya ikan ini sering dikatakan tidak begitu dipengaruhi oleh upaya penangkapan yang ada sekarang ini.

Namun, dengan tidak adanya informasi tentang potensi lestari spesies ini, maka produksi yang stabil selama 5 tahun terakhir dapat menjadi indikator bahwa telah terjadi keseimbangan antara upaya penangkapan, produksi, dan potensi lestari. Dengan kata lain, pengembangan perikanan tenggiri papan dilakukan dengan hati-hati. Ekspansi besar-besaran memang tidak direkomendasikan.

Indonesia adalah produser utama tenggiri papan di kawasan Samudera Hindia dengan produksi pada tahun 2005 mencapai 14.300 ton. Produksi Indonesia juga cenderung konstan selama 5 tahun terakhir. Negara produsen lainnya yaitu India dan Iran. Indonesia menggunakan gill net untuk menangkap ikan ini. India menggunakan gill net dan pancing. Saudi Arabia, Yaman, dan Pakistan dalam tahuntahun terakhir ini mulai mengembangkan armada gill net untuk menangkap ikan ini.

\section{TENGGIRI (Scomberomerous sp.)}

Tenggiri (Scomberomerous sp.) atau spanish mackerel (king seer) merupakan ikan pelagis yang termasuk predator tingkat tinggi yang ditemukan hidup di perairan tropis sekitar pulau-pulau yang berada di sebelah timur Samudera Hindia. Ikan dewasa dijumpai dalam gerombolan kecil. Ikan ini juga sering berkumpul di sekitar terumbu karang untuk memijah dan mencari makan. Namun demikian, spesies ini juga melakukan migrasi yang cukup jauh dari suatu perairan pantai ke perairan pantai lain. Tenggiri memangsa ikan-ikan berukuran kecil seperti teri, cumi, dan udang. 
Tenggiri dapat hidup sampai 15 tahun dan mencapai $240 \mathrm{~cm}$ panjang dan $70 \mathrm{~kg}$ bobot. Pemijahan dilakukan hampir sepanjang tahun dengan puncak pada bulan April sampai Juli dan bulan September sampai Nopember. Ini berarti ada 2 musim puncak pemijahan yang membuat rekruitmen tenggiri (Scomberomerous $\mathrm{sp}$.) cukup tinggi yang pada akhirnya membuat jenis ini tidak terlalu diganggu oleh tingkat upaya penangkapan yang ada saat ini.

Dengan data yang ada belum dapat dilakukan pendugaan stok serta potensi lestarinya. Produksi rata-rata tahunan selama tahun 2001 sampai 2005 mencapai 117.726 ton. Produksi tahun 2005 adalah 118.240 ton. Dengan stabilnya produksi, diperkirakan bahwa stok dan potensi sumber dayanya dalam keadaan aman untuk dieksploitasi.

Produksi Indonesia mencapai 28.700 ton pada 2005 , berada di bawah produksi India yang mencapai 44.700 ton. Negara produsen lain yaitu Oman, Pakistan, Iran, Uni Emirat Arab, dan Malaysia yang tingkat produksnyai kurang dari 10.000 ton. Namun demikian, ikan yang tertangkap di kawasan barat Samudera Hindia, khususnya di Laut Arab, cenderung lebih ukurannya dari yang ada di kawasan timur Samudera Hindia, termasuk kepulauan Indonesia. Dengan demikian, sementara ini dapat dikatakan bahwa sumber daya ikan tenggiri di Samudera Hindia bukan 1 populasi. Hal ini berarti bahwa pengelolaan sumber daya ini dilakukan secara lokal dengan mempertimbangkan perkembangan upaya penangkapan di setiap kawasan.

\section{IMPLIKASI BAGI PERIKANAN INDONESIA}

Setelah mengetahui status potensi ikan tuna dan sejenisnya di Samudera Hindia, maka dapat ditarik implikasinya bagi pembangunan perikanan Indonesia.

Pertama, dari sisi sumber daya ikan ternyata hanya beberapa spesies saja (terutama jenis tongkol) yang dapat dikatakan terdiri atas beberapa populasi atau sub populasi yang berbeda. Ini berarti bahwa sumber daya perikanan tuna dan sejenisnya di Samudera Hindia dapat dikatakan sebagai 1 populasi besar yang mendiami habitat Samudera Hindia. Sebagai 1 populasi, hal tersebut berarti bahwa interaksi antar negara, antar industri penangkapan, antar teknologi penangkapan ikan, antar nelayan, dan bahkan antar spesies yang hidup di habitat yang sama ini sangat mungkin terjadi. Dari sisi implikasi kebijakan, itu berarti bahwa kebijakan suatu negara tidak terisolasi terhadap kebijakan negara lain. Dengan kata lain, kebijakan suatu negara mungkin tidak efektif bila tidak mempertimbangkan kebijakan negara lainnya. Kondisi sumber daya yang terdiri atas populasi yang besar ini juga menjadi justifikasi bagi keberadaan Regional Fisheries Management Organization-Indian Ocean Tuna Commission sebagai suatu entitas pengelola sumber daya perikanan regional Samudera Hindia.

Kedua, meskipun dikelola secara bersama oleh entitas regional, kompetisi antara negara tidak terelakan, dan mungkin akan terus berlanjut selagi setiap negara yang ada di kawasan Samudera Hindia (negara pantai), atau negara lain (bukan negara pantai), memiliki kepentingan sendiri, kepentingan nasional, yang perlu dicapai, dikejar, atau dilindungi. Ini berarti bahwa bila sumber daya ikan yang tersedia di Samudera Hindia ini tidak dimanfaatkan oleh 1 negara, maka kesempatan ini akan diambil oleh negara lain. Bila Indonesia tidak memanfaatkan sumber daya ikan di 
Samudera Hindia, maka negara lain akan memanfaatkannya.

Ketiga, ternyata sumber daya perikanan Samudera Hindia telah dimanfaatkan sejak awal 1950-an, masih terus berlangsung dengan semarak hingga saat ini, dan mungkin akan terus dimanfaatkan oleh banyak negara hingga beberapa dekade yang akan datang. Selagi sumber daya ikan tersedia, sejauh itu pula kegiatan pemanfaatan (eksploitasi) sumber daya tersebut akan terus berlangsung. Tetapi yang lebih menarik yaitu bahwa pemanfaatan sumber daya ikan di Samudera Hindia ini melibatkan banyak negara, bukan negara pantai tetapi juga negara lain yang jauh letaknya dari Samudera Hindia. Keikutsertaan negara-negara yang tidak berbatasan langsung dengan Samudera Hindia ini, apalagi ternyata negara-negara tersebut memiliki teknologi penangkapan ikan yang lebih maju akan lebih memperkecil peluang negara-negara pantai seperti Indonesia untuk memanfaatkan sumber daya ikan yang tersedia. Fakta yang ada tentang hal ini yaitu sejak 1950an, negara-negara maju ikut menangkap ikan di Samudera Hindia dengan teknologi penangkapan yang lebih maju, lebih besar skala, lebih efisien, dari yang digunakan di Indonesia (FAO, 2005).

Keempat, sumber daya tuna dan sejenisnya, terutama jenis tuna ukuran besar seperti tuna albakora (Thunnus alalunga), tuna mata besar (Thunnus obesus), dan madidihang (Thunnus albacares) boleh dikatakan sudah dimanfaatkan secara penuh, atau telah melebihi potensi lestarinya. Produksi tahun 2005 untuk ke-3 spesies tuna ini lebih kecil dari produksi beberapa tahun sebelumnya. Juga ada indikasi bahwa ikan yang tertangkap semakin kecil ukurannya, suatu tanda bahwa sumber daya telah mulai mengalami degradasi atau deplesi. Di pihak lain, jenis tuna yang berukuran sedang dan kecil, umpamanya cakalang (Katsuwonus pelamis), tongkol (Euthynnus affinis), dan tenggiri (Scomberomerous sp.), serta ikan pedang (Xiphius gladius), cenderung belum dimanfaatkan secara penuh yang berarti bahwa pengembangan perikanan jenis-jenis ini terbuka peluangnya.

Kondisi tingkat pemanfaatan sumber daya seperti ini mungkin juga merupakan refleksi dari permintaan pasar yang memang tinggi nilainya bagi jenis tuna ukuran besar. Sementara itu, ikan tuna berukuran kecil rendah nilainya di pasar dunia dan karena itu cenderung dikonsumsi secara domestik. Harga dan permintaan dunia seperti ini pula mendorong negara-negara Eropa (Perancis dan Spanyol) serta Jepang, Korea, Cina, dan Taiwan menangkap tuna ukuran besar secara intensif dengan armada penangkapan ikan yang lebih maju. Negaranegara ini tidak begitu menaruh perhatian untuk memanfaatkan tuna ukuran kecil, sebaliknya membiarkan untuk dimanfaatkan oleh negara-negara pantai, atau negara yang kecil industri perikanan seperti Indonesia.

Indonesia tidak dapat tinggal diam atau hanya mengikuti pola pemanfaatan sumber daya ikan yang sudah ada saat ini. Bila pola seperti ini terus berlangsung, maka negaranegara besar tadi terus menikmati keuntungan yang dihasilkan karena kelangkaan sumber daya (pemasokkan) dan besarnya permintaan pasar dunia. Sementara dan setelah menikmati keuntungan itu, kebijakan konservasi sumber daya mungkin sekali diterapkan yang membuat negara lain, termasuk Indonesia, kecil peluangnya untuk mengembangkan industri penangkapan ikan.

Karena itu maka Indonesia mengembangkan industri perikanan 
tangkap yang diarahkan pada 2 pola besar tadi, yaitu mengembangkan industri perikanan tangkap untuk memanfaatkan sumber daya tuna albakora, madidihang, dan tuna mata besar dengan teknologi yang setara dengan negara lain dan terus mengembangkan secara besar-besaran industri perikanan untuk memanfaatkan sumber daya cakalang, jenis-jenis tongkol, jenis-jenis tenggiri, dan ikan pedang (sword fish dan bill fish). Pengembangan pola yang ke-2 ini sebaiknya ditempuh dengan penguatan atau pemberdayaan perikanan artisanal, perikanan rakyat, atau perikanan skala kecil.

Kelima, karena sumber daya ikan Samudera Hindia dikelola bersama oleh Indian Ocean Tuna Commission, maka keikutsertaan Indonesia sebagai anggota aktif dan penuh Indian Ocean Tuna Commission adalah suatu keharusan. Dengan ikutserta Indonesia sebagai anggota aktif dan penuh Indian Ocean Tuna Commission, maka hal tersebut akan menjamin keberlanjutan dan pengelolaan sumber daya, memiliki jatah atau kuota penangkapan yang direalisasikan melalui alokasi upaya penangkapan dan jumlah armada, mempermudah Indonesia dalam lobi internasional dalam rangka pengembangan pasar ekspor, serta membuka kesempatan bagi Indonesia dalam pengambilan keputusan di tingkat Indian Ocean Tuna Commission.

\section{DAFTAR PUSTAKA}

Indian Ocean Tuna Commission. 2008. Conservation and management Measures Adopted by Indian Ocean Tuna Commission at it Twelfth Regular Session. Indian Ocean Tuna Commission Circular. 07-08.

Ward, T., D. Tarte, E. Hegeri, \& K. Short. 2002. Policy proposals and operational guidance for ecosystem-based fisheries management of capture fisheries. WWF. $77 \mathrm{pp}$.

FAO. 2005. Review of the state of world marine fisheries resource. FAO Fisheries Technical Paper. 457. 20 pp. 